\title{
KARAKTERISTIK PENDIDIKAN DAN UNSUR-UNSUR KELEMBAGAAN DI PESANTREN
}

\author{
Abu Anwar \\ Universitas Islam Negeri Sultan Syarif Kasim Riau, Indonesia \\ Email: abuanwar@uin-suska.ac.id
}

\begin{abstract}
Pesantren is basically a traditional Islamic education where the students lived with and studied under the guidance of one (or more) teachers are better known as kyai. Although pesantren was considered traditional, but still exist and survive in modern age and global era. Obviously because this institution has its own characteristics and maintain institutional elements that have formed since former. The characteristics of education in pesantren classified to two: (1) the general pattern of education, which are pesantren institutions introducing levels, from that teach simple texts until sublime pesantren that teach high level texts. (2) Teaching systems are the sorogan system and bandongan system. As for the institutional elements in pesantren are cottage, mosques, students, kyai, classical Islamic books.
\end{abstract}

Keywords: pesantren, kyai, Islamic education, institution.

\section{A. Pendahuluan}

Pesantren merupakan tradisi Islam Indonesia yang tidak semua negara memiliki sistem pendidikan tersebut. Hanya beberapa negara tertentu yang tetap meneruskan tradisi lembaga berbentuk pesantren. Bahkan, negeri Selangor Malaysia dan Pakistan sekalipun, menerapkan kebijakan untuk melakukan transformasi pondok pesantren ke sekolah berasrama. Untuk itu, kekhasan tradisi pendidikan Indonesia yang wujud dalam bentuk pesantren patut disyukuri sebagai anugerah.

Saat ini, pesantren menjadi pusat segala bentuk kehidupan umat Islam. Tidak hanya menjadi tempat belajar yang memang merupakan fungsi pokok pesantren tetapi lebih dari itu, pesantren telah berkembang menjadi pusat ekonomi, sosial politik, kemasyarakatan dan pemberdayaan masyarakat. Sebagai lembaga sosial, pesantren telah menjawab kebutuhan akan pendidikan murah dan berkualitas. Sekaligus menampung 
peserta didik dari semua lapisan masyarakat muslim tanpa membeda-bedakan tingkat sosial ekonomi orangtua.

Jumlah lembaga pendidikan pesantren di Indonesia tidak kurang dari 17.000 buah. Dengan jumlah sebesar itu, logis jika sumbangan pesantren-pesantren terhadap dinamika kebangsaan sangat signifikan. Bahkan sebelum Negara Kesatuan Republik Indonesia terbentuk, pesantren telah jadi garda terdepan bagi lahirnya pejuang bangsa untuk membela harkat dan martabat rakyat Indonesia. Setelah kemerdekaan, kontribusi pesantren terus berlanjut hingga hari ini, sehingga menjadi satu kesyukuran berikutnya, kita di antara ratusan juta umat Islam di Indonesia, sedikit yang mampu mengalami proses kehidupan di pesantren.

Tokoh pendidikan seperti Dr Soebardi dan Prof Johns (1982) ketika ditanyakan tentang lembaga pendidikan yang ideal bagi pengembangan karakter dan watak bangsa Indonesia, dengan tanpa ragu-ragu keduanya menyepakati pesantren sebagai jawaban. Demikian pula pengembangan sekolah unggulan seperti SMA Taruna Nusantara dan sekolah unggulan lain yang tersebar di semua propinsi senantiasa mengambil pesantren sebagai prototipe dalam membangun kecemerlangan pendidikan. Hal ini menjadi bukti kongkrit, sesungguhnya keberadaan lembaga pendidikan pesantren adalah bentuk modernisasi yang menjadi pilihan sadar bangsa Indonesia. Alberto Guerreiro Ramos (1980) menyatakan bahwa setiap bangsa berhak memilih dan menentukan model pembangunan nasionalnya sendiri, termasuk di dalamnya sistem pendidikan nasional. Pola modernisasi yang ditiru bangsa lain hanya mungkin dilakukan jika tidak ada kemungkinan-kemungkinan modernisasi sendiri. Maka, pesantren telah menjadi jawaban modernisasi untuk bangsa Indonesia.

\section{B. Ciri-ciri Pesantren dan Pendidikan di Pesantren}

\section{Ciri-ciri Pesantren}

Sebuah pesantren pada dasarnya adalah sebuah asrama pendidikan Islam Tradisional di mana para siswa tinggal bersama dan belajar di bawah bimbingan seorang (atau lebih) guru yang lebih dikenal dengan sebutan kyai. Berdasarkan jumlah siswa atau santri, pesantren dapat dikelompokkan menjadi tiga macam, antara lain: pesantren kecil, yaitu pesantren yang biasanya mempunyai jumlah santri di bawah 
seribu dan pengaruhnya terbatas pada tingkat kabupaten, pesantren menengah, yaitu pesantren yang memiliki jumlah santri antara 1000 sampai dengan 2000 orang, pesantren menengah ini biasanya memiliki pengaruh dan menarik santri-santri dari beberapa kabupaten, dan pesantren besar, yaitu pesantren yang mempunyai jumlah santri lebih dari 2000 orang yang berasal dari berbagai kabupaten dan propinsi. Beberapa pesantren besar memiliki popularitas yang dapat menarik santri-santri dari seluruh Indonesia, bahkan menarik santri dari luar negeri, seperti Pesantren Gontor di Ponorogo, Jawa Timur.

Selain itu, dikenal pula istilah-istilah pesantren, seperti: Pesantren Tradisional, Pesantren Modern dan Pesantren Kilat. Pesantren tradisional atau pesantren salafi adalah pesantren yang tetap mempertahankan pengajaran kitab-kitab Islam klasik sebagai inti pendidikan di pesantren. Sistem madrasah atau jenjang-jenjang juga diterapkan untuk lebih memudahkan sistem pengajaran yang dipakai dalam lembagalembaga pengajian bentuk lama, pesantren ini tidak mengenalkan pengajaran pengetahuan umum. Misalnya, Pesantren Lirboyo dan Ploso di Kediri, Pesantren Aslakul Huda di Pati dan pesantren Tremas di Pacitan. Pesantren modern atau pesantren khalafi adalah pesantren yang telah memasukkan pelajaran-pelajaran umum dalam sistem madrasah-madrasah yang dikembangkannya, atau membuka tipe sekolah umum dalam lingkungan pesantren. Misalnya, Pondok Modern Gontor di Ponorogo yang tidak lagi mengajarkan kitab-kitab Islam klasik atau Pesantren Tebuireng dan Rejoso di Jombang yang telah membuka SMP, SMA dan universitas namun tetap mempertahankan pengajaran kitab-kitab Islam klasik. Adapun pesantren kilat merupakan kegiatan dalam pesantren yang diselenggarakan hanya dalam beberapa minggu saja (15-40 hari). Aktifitas ini biasanya bertujuan untuk mengisi waktu kosong (libur) dari para santri maupun orang di luar pesantren (anak-anak yang bersekolah di sekolah umum) dengan belajar dan memperdalam pengetahuan mereka tentang Islam dan amalan-amalan yang harus dilakukan, seperti: sholat, membaca Al-Qur'an, belajar bahasa Arab, menghafalkan doa-doa dan sebagainya. Biasanya para orang tua yang mempunyai anak yang bersekolah di sekolah umum mengirim mereka ke pesantren kilat supaya anak mereka memiliki pengetahuan yang seimbang antara pengetahuan umum 
dan agama. Pesantren kilat ini biasanya diselenggarakan pada masa liburan sekolah umum atau pada bulan Ramadhan.

\section{Karakteristik Pendidikan di Pesantren}

Zamakhsyari Dhofier mengatakan, karakteristik pendidikan di pesantren terlihat dari bangunan-bangunan yang sengaja dibuat sederhana, sekaligus menekankan kesederhanaan cara hidup para santri. ${ }^{1}$ Oleh karenanya, kehidupan pondok pesantren adalah kehidupan dengan pola hidup mandiri, santri dituntut dapat mengurus dirinya terutama kebutuhan badaniyahnya atau tidak tergantung pada orang lain kecuali kepada Allah. Dalam belajar kitab-kitab klasik, kyai menuntut pemebelajaran individual, artinya santri dituntut mampu belajar secara mandiri dan berusaha membaca kitab-kitab yang lebih besar setelah kyai memberikan dasar dalam mempelajarinya. ${ }^{2}$ Dengan pola seperti ini akan terlihat santri yang pintar dan kurang pintar.

Gambaran dari karakteristik pendidikan di pesantren dapat diklasifikasikan kepada dua hal yakni pola umum pendidikan dan sisem pengajaran.

\section{a. Pola Umum Pendidikan}

Pola pendidikan Islam tradisional di lembaga-lembaga pengajian atau pesantren sangat berbeda-beda. Pada umumnya bertingkat-tingkat sesuai dengan usia atau kebutuhan murid apakah dia ingin menjadi ulama atau tidak. Tingkatan pengajian yang paling rendah dimulai pada waktu anak-anak berumur sekitar 5 sampai 7 tahun dalam bentuk membaca atau menghafalkan surat-surat pendek dari Al-Qur'an yang dikenal dengan nama turutan, yang dilanjutkan, secara bertahap, membaca seluruh Al-Qur'an sampai lancar sekali, baik dalam pengenalan huruf-huruf atau tulisan-tulisan Arab maupun pengucapannya. Untuk mencapai taraf ini biasanya diperlukan waktu sekitar 5 atau 6 tahun. Proses seleksi terhadap murid-murid yang pandai sudah terjadi dalam tingkatan ini. ${ }^{3}$

Pengajian pada tingkat yang lebih tinggi berbentuk penerjemahan ke dalam bahasa Jawa terhadap teks-teks Islam klasik yang masih bersifat elementer baik yang

${ }^{1}$ Zamakhsyari Dhofier, Tradisi Pesantren, LP3ES, Jakarta, 1982, hlm. 16-17

${ }^{2}$ Kepatuhan santri kepada kyainya, dan dalam beberapa hal, pelajaran-pelajaran dasar mengenai kitab-kitab Islam klasik menjadi salah satu aspek penting dalam pembelajaran di pesantren. Dhofier mengemukakan, kehidupan politik juga mewarnai kehidupan santri dan merupakan bagian dari kehidupan pesantren, tetapi perjuangan politik tidak dianggap sebagai suatu kepentingan pokok.

${ }^{3}$ Zamakhsyari Dhofier, op.cit., hlm. 20 
mengenai tata bahasa Arab, hukum-hukum Islam maupun teologi Islam. Setelah murid memperoleh dasar-dasar yang cukup dalam sistem pengajian ini, barulah ia dianggap qualified untuk meneruskan pelajarannya ke lembaga-lembaga pesantren yaitu sekitar 15 atau 16 tahun. Lembaga-lembaga pesantrenpun mengenalkan tingkatan-tingkatan, dari yang mengajarkan teks-teks sederhana sampai kepada pesantren luhur yang mengajarkan teks-teks tingkat tinggi. Untuk masa sekarang murid dapat memperolehnya pada Institut Agama Islam Negeri (IAIN). ${ }^{4}$

Dewasa ini, walau setelah Indonesia merdeka dan telah berkembang jenis-jenis pendidikan Islam formal dalam bentuk madrasah, namun secara luas, kekuatan pendidikan Islam di Jawa masih berada pada sistem pesantren. Posisi dominan yang dipegang oleh pesantren disebabkan suksesnya lembaga pesantren menghasilkan sejumlah besar 'ulama' yang berkualitas tinggi yang dijiwai oleh semangat untuk menyebarluaskan dan memantapkan keimanan orang-orang Islam. ${ }^{5}$ Di sisi lain, figur kyai yang begitu kuat dan penguasaannya terhadap ilmu pengetahuan agama menjadikan pesantren sebagai pusat pendidikan dan dakwah Islam. Pesantren memainkan peranan penting dalam penyebaran di pedalaman pula Jawa. Bahkan ada kemungkinan beberapa pesantren mengambil alih pusat-pusat keagamaan pra Islam. ${ }^{6}$

Sebagai pusat-pusat pendidikan Islam, pesantren juga mendidik guru-guru madrasah, guru-guru lembaga pengajian dan para khatib Jum'at. Keberhasilan pemimpin-pemimpin pesantren dalam menelorkan sejumlah besar ulama yang berkualitas tinggi adalah karena metode pendidikan yang dikembangkan para kyai. Tujuan pendidikan tidak semata-mata untuk memperkaya pikiran murid dengan penjelasan-penjelasan, tetapi untuk meninggikan moral, melatih dan mempertinggi semangat, menghargai nilai-nilai spritual dan kemanusiaan, mengajarkan sikap dan tingkah laku yang jujur dan bermoral, dan menyiapkan para siswa untuk hidup sederhana dan bersih hati.

Zamakhsari menambahkan, di antara cita-cita pendidikan pesantren adalah latihan untuk dapat berdiri sendiri dan membina diri agar tidak menggantungkan sesuatu kepada orang lain kecuali kepada Tuhan. Para kyai selalu menaruh perhatian dan

\footnotetext{
${ }^{4}$ Ibid.

${ }^{5}$ Ibid. hlm. 110

${ }^{6}$ Hilmy Muhammadiyah dan Sulthan Fatoni, NU Identitas Islam Indonesia, Elsas, Jakarta, 2004,
} 
mengembangkan watak pendidikan individual. Anak-anak yang cerdas dan memiliki kelebihan kemampuan daripada yang lain diberi perhatian istimewa dan selalu didorong untuk terus mengembangkan diri dan menerima kuliah pribadi secukupnya. Muridmurid juga diperhatikan tingkah laku moralnya secara teliti. Mereka diperlukan sebagai makhluk yang terhormat sebagai titipan Tuhan yang harus disanjung. Kepandaian berpidato dan berdebat betul-betul dikembangkan. Kepada murid ditanamkan perasaan kewajiban dan tanggungjawab untuk melestarikan dan menyebarkan pengetahuan tentang Islam kepada orang lain, mencurahkan waktu dan tenaga untuk belajar, terusmenerus sepanjang hidup. ${ }^{7} \quad$ Menurut tradisi pesantren, pengetahuan seseorang diukur oleh jumlah buku-buku yang telah pernah dipelajarinya dan kepada ulama mana ia telah berguru. Jumlah buku-buku standar dalam tulisan Arab yang dikarang oleh ulama terkenal yang harus dibaca dan telah diutentukan oleh lembaga-lembaga pesantren. Kemudian masing-masing kyai dari berbagai pesantren biasanya mengembangkan diri untuk memiliki keahlian dalam cabang pengetahuan tertentu, di mana kitab-kitab yang dibaca juga cukup dikenal. Dengan demikian, homogenitas pandangan hidup keagamaan terbina dengan baik, tapi di samping itu sifat kekhususan seorang kyai juga dapat tersalur.

\section{b. Sistem Pengajaran}

Sistem pengajaran yang dikenalkan di pesantren pada umumnya ada dua macam, yaitu sistem sorogan, sistem ini biasanya diberikan kepada murid-murid yang telah menguasai pembacaan Al-Qur'an. Sistem ini merupakan sistem pengajian dasar di rumah-rumah, di langgar dan di masjid yang diberikan secara individual. Dalam sistem ini guru membaca beberapa baris ayat al-Qur'an atau kitab-kitab bahasa Arab dan menerjemahkannya ke dalam bahasa Jawa. Kemudian murid mengulangi dan menerjemahkan kata demi kata sepersis mungkin seperti yang dilakukan oleh gurunya. Dalam sistem ini murid diharapkan dapat menguasai tata bahasa Arab dan artinya dengan benar.

Sistem bandongan merupakan sistem utama di lingkungan pesantren. Dalam sistem ini sekelompok murid mendengarkan seorang guru yang membaca, menerjemahkan kata demi kata, dan menerangkan maksudnya. Santri menyimak kitab

\footnotetext{
${ }^{7}$ Zamakhsyari Dhofier, op.cit., hlm. 22
} 
masing-masing dan mendengarkan dengan seksama terjemahan dan penjelasan kyai. Kemudian santri mengulang dan mempelajari kembali sendiri-sendiri. Pada tingkat halaqah yang lebih tinggi, sebelum santri mengikutinya, harus terlebih dahulu mempelajari bagian-bagian dari kitab yang akan diajarkan kyai, sehingga santri tinggal menyimak bacaan kyai dan mencocokkan pemahamannya dengn keterangan kyai. ${ }^{8}$

Dengan melalui halaqah para santri juga dimotivasi untuk belajar sendiri secara mandiri. Bagi santri yang rajin dan mempunyai kecerdasan yang tinggi tentunya akan cepat menguasai apa yang diajarkan.

Dalam realitasnya, penyelenggaraan sistem pendidikan dan pengajaran di pondok pesantren dewasa ini dapat digolongkan kepada 3 bentuk:

1) Pondok pesantren adalah lembaga pendidikan dan pengajaran agama Islam, yang pada umumnya diberikan dengan cara nonklasikal (sistem bandongan dan sorogan) di mana seorang kyai mengajar santri berdasarkan kitab-kitab yang ditulis dalam bahasa Arab oleh ulama-ulama besar sejak abad pertengahan, sedang para santri biasanya tinggal dalam pondok ataun asrama dalam pesantren.

2) Pondok pesantren adalah lembaga pendidikan dan pengajaran agama Islam, yang pada dasarnya sama dengan pondok pesantren, tetapi para santri tidak disediakan pondok, namun tinggal dan tersebar di seluruh penjuru desa sekeliling pesantren (santri kalong), di mana cara dan metode pendidikan dan pengajaran diberikan dengan sistem weton, yaitu cara santri datang berduyunduyun pada waktu-waktu tertentu.

3) Pondok pesantren dewasa ini merupakan lembaga gabungan antara sistem pondok dan pesantren yang memberikan pendidikan dan pengajaran dengan sistem bandongan, sorogan atau wetonan dengan para santri kalongan, yang dalam istilah pendidikan pondok modern memenuhi kriteria pendidikan nonformal, serta menyelenggarakan pendidikan formal berbentuk madrasah

${ }^{8}$ Mahmud Yunus, Sejarah Pendidikan Islam di Indonesia, Hidakarya Agung, Jakarta, 1985, hlm. 
dan bahkan sekolah umum dalam berbagai banyak tingkatan dan aneka kejuruan menurut kebutuhan masyarakat. ${ }^{9}$

Amin Rais menambahkan, dalam sistem kerjanya, sistem yang ditampilkan pondok pesantren dalam pendidikan dan pengajarannya mempunyai keunikan dibandingkan dengan sistem yang diterapkan pada pendidikan umum yaitu:

1) Memakai sistem tradisional yang mempunyai kebebasan penuh dibandingkan dengan sekolah modern, sehingga terjadi hubungan dua arah antara santri dan kyai

2) Kehidupan di pesantren menampakkan semangat demokrasi karena mereka praktis bekerja sama mengatasi problema nonkurikuler mereka

3) Para santri tidak mengidap penyakit simbolis, yaitu perolehan gelar dan ijazah, karena sebagian besar pesantren tidak mengeluarkan ijazah, sedangkan santri dengan ketulusan hati masuk pesantren tanpa adanya ijazah, hal itu karena tujuan utama mereka hanya ingin mencari keridhaan Allah SWT

4) Sistem pondok pesantren mengutamakan kesederhanaan, idealisme, persaudaraan, persamaan, rasa percaya diri dan keberanian hidup

5) Alumni pondok pesantren tidak ingin menduduki jabatan pemerintahan, sehinga mereka hampir tidak dapat dikuasai oleh pemerintah. ${ }^{10}$

\section{Unsur-unsur Kelembagaan Pesantren}

\section{Pondok}

Pada awal perkembangannya, pondok bukanlah semata-mata dimaksudkan sebagai tempat tinggal atau asrama para santri, untuk mengikuti dengan baik pelajaran yang diberikan oleh kyai, tetapi juga sebagai tempat training bagi santri yang bersangkutan agar mampu hidup mandiri dalam masyarakat. Namun dalam perjalanan waktu, terutama pada masa sekarang, tampaknya lebih menonjol fungsinya sebagai

${ }^{9}$ Depag RI, Pedoman Pembinaan Pondok Pesantren, Ditjen. Binbaga Islam, Jakarta, 1985, hlm.

${ }^{10}$ Amin Rais, Cakrawala Islam, Antara Cita dan Fakta, Mizan, Bandung, 1989, hlm. 162 
tempat pemondokan atau asrama, dan setiap santri dikenakan semacam sewa atau iuran untuk pemeliharaan pondok.

Biasanya, pembangunan pondok bagi santri dibagun di atas tanah milik kyai, walaupun dalam perkembangannya sudah banyak pemondokan didirikan di atas tanah milik masyarakat yang diwakafkan ke pondok pesantren. Pemondokan bagi santri merupakan ciri khas dari pondok pesantren dengan sistem pendidikan tradisional sedang pada sistem modern hanya menyediakan gedung belajar dan santri pulang pergi dari rumah mereka atau sebagaian dari mereka menyewa rumah penduduk di sekitar pondok.

Harun Nasution mengatakan, transformasi pesantren telah terjadi tidak saja dalam sarana, tetapi juga dalam sistem pendidikannya; di samping sistem salafi juga madrasi dan bahkan digabung dengan pengembangan keterampilan tangan. Meskipun demikian, pesantren tetap melestarikan tradisi utamanya yaitu pembinaan moral untuk selalu berbuat sopan santun, semangat mencari ilmu dan sikap hidup mandiri. ${ }^{11}$ Walau santri dalam format pesantren modern bisa pulang pergi dari rumah mereka, bukan berarti lepas dari kontrol/pantauan pesantren. Tetapi dengan sederetan aktivitas kepesantrenan justru diharapakan akan muncul nilai-nilai dan tradisi keislaman yang mengakar kuat dalam jiwa santri.

Di Jawa sendiri pemondokan dibangun sesuai dengan jumlah santri yang menuntut ilmu. Semakin besar jumlah santri, maka semakin banyak asrama yang dibutuhkan dan ini dibebankan kepada santri dan wali santri dengan uang sumbangan pembangunan. Sebagai contoh Pondok Pesantren Darussalam, blok Agung di Banyuwangi mewajibkan para santri membanyar Rp. 6.000, / setahun, menyediakan sepotong kayu bangunan, satu meter kubik pasir dan diwajibkan membuat 200 buah batu bata setahun sekali. Pesantren Ploso di Kediri mewajibkan para santrinya membayar uang pondok sebanyak Rp. 7.000,- setahun, dan mengumpulkan zakat dari orang-orang kaya di kampung asal santri di waktu musim panen untuk kepentingan perluasan bangunan dalam lingkungan pesantren.

Ada tiga alasan pondok pesantren menyediakan pemondokan bagi santri. Pertama, kemasyhuran seorang kyai, kedalaman pengetahuan agamanya menarik santrisantri dari jauh untuk menuntut ilmu dari kyai tersebut sehingga untuk dapat

\footnotetext{
${ }^{11}$ Nurcholis Madjid, Bilik-bilik Pesantren, Paramadina, Jakarta, 1997, hlm. xv.
} 
memaksimalkan diri menuntut ilmu santri harus menetap di dekat kediaman kyai. Kedua, hampir semua pesantren berada di desa-desa terpencil di mana tidak tersedia perumahan atau penginapan yang cukup untuk santri, dengan demikian secara tidak langsung perlu adanya asrama bagi santri jauh. Ketiga, ada sikap timbal balik antara kyai dan santri, di mana para santri menganggap kyainya seolah-olah sebagai bapaknya sendiri, dan kyai menganggap para santri sebagai titipan Allah yang harus dilindungi. Sikap saling membutuhkan ini menimbulkan rasa tanggung jawab kyai untuk menyediakan asrama bagi santri, dan tumbuh dalam diri santri sikap selalu taat kepada kyai.

Keadaan asrama biasanya sangat sederhana, cukup untuk berteduh dan menaruh beberapa barang pribadi sehingga santri yang kaya pun harus puas dengan keadaan seperti itu. Beberapa dapur juga disediakan bagi santri yang memasak, sedangkan yang lainnya bisa berlangganan makan di warung sekeliling pesantren, 2 atau 3 kali makan dengan membayar uang di muka untuk satu bulan yang rata-rata bayarannya Rp. 4.000 sampai dengan Rp. 6.000 atau lebih, tergantung dari jenis lauk-pauk makanannya. Untuk tempat tinggal santri putri biasanya terpisah dari asrama putra dan keadaannnya pun tidak jauh berbeda dengan arsama untuk santri putra.

\section{Masjid}

Keberadaan masjid tidak terlepas dari dunia pendidikan Islam karena ia adalah salah satu pusat pengembangan ajaran Islam pada masa awal Islam. Keberadaannya yang sangat vital menuntut pondok pesantren untuk membangun masjid dalam pesantren sebagai tempat mendidik para santri, shalat lima waktu, dan pengajian kitabkitab klasik. Seorang kyai yang ingin mengembangkan sebuah pondok pesantren biasanya pertama-tama akan mendirikan masjid di dekat rumahnya.

Masjid yang telah dibangun dijadikan sebagai tempat/lembaga pendidikan bagi santri dalam pelatihan-pelatihan dan pendidikan elementer yang secara tradisional diberikan dalam pengajian-pengajian. Terkadang rumah kyai, rumah guru dan langgarlanggar juga menjadi tempat penyelenggaraan pengajian (pendidikan). Dalam perkembangan terakhir menunjukkan, di dalam mesjid terdapat ruangan-ruangan yang berupa kelas-kelas sebagaimana terdapat di madrasah-madrasah. Namun demikian, 
masjid masih tetap digunakan sebagai temapat belajar-mengajar. ${ }^{12}$ Pada sebagian pesantren masjid berfungsi sebagai tempat i'tikaf dan melaksanakan latihan-latihan, atau suluk dan dzikir, maupun amalan-amalan dalam kehidupan tarekat dan sufi. ${ }^{13}$

Sebagai lembaga pendidikan, masjid atau langgar mempunyai fungsi yang tidak terlepas dari kehidupan keluarga. Sebagai lembaga pendidikan, berfungsi sebagai penyempurna pendidikan dalam keluarga, agar selanjutnya anak mampu melaksanakan tugas-tugas hidup dalam masyarakat dan lingkungannya. Pada mulanya pendidikan di langgar atau di masjid, dalam arti sederhana dapat dikatakan sebagai lembaga pendidikan formal, dan sekaligus lembaga pendidikan sosial.

Pada tahap-tahap awal, penyelenggaraan pendidikan antara langgar atau surau dibedakan dengan masjid, di mana pendidikan di surau atau langgar adalah pendidikan tingkat dasar yang biasa disebut pengajian al-Qur'an. Kemudian pendidikan dan pengajaran di tingkat lanjutan disebut pengajian kitab dan diselenggarakan di masjid. Dengan demikian, di seurau atau di langgar dan masjid pada masa lalu (sebelum timbul dan berkembangnya madrasah), telah diselenggarakan dua macam starata pendidikan yaitu pendidikan dasar, yang disebut pengajian al-Qur'an, pendidikan ini berada di bawah bimbingan guru mengaji al-Qur'an. Dan yang kedua, pendidikan tingkat lanjutan yang disebut Guru Kitab. ${ }^{14}$

Zamakhsari Dhofier menekankan, semua lembaga-lembaga pengajian tidak sama jenisnya; dalam kenyataannya lembaga-lembaga tersebut bertingkat-tingkat. Bentuk yang paling rendah bermula pada waktu anak-anak berumur 5 tahun, menerima pelajaran dari orang tuanya menghafalkan beberapa surat pendek dari juz Qur'an yang terakhir. Setelah mereka berumur 7 atau 8 tahun mulai diajarkan membaca alfabet Arab dan secara bertahap diajar untuk dapat membaca al-Qur'an. Pengajarnya biasanya orang

\footnotetext{
${ }^{12}$ Hasan Langgulung menegaskan, masjid merupakan lembaga kedua setelah keluarga, yang jenjang pendidikannya terdiri dari sekolah menengah dan sekolah tinggi dalam waktu yang sama, lihat Hasan Langgulung, Asas-asas Pendidikan Islam, al-Husna Dzikra, Jakarta, 1988, hlm. 111. Abdurrahman an-Nahlawi menyeburkan, implikasi masjid sebagai lembaga pendidikan meliputi 3 aspek: (a) mendidik anak untuk tetap beribadah kepada Allah; (b) menanamkan rasa cinta kepada ilmu pengetahuan dan menanamkan solidaritas sosial serta menyadarkan hak-hak dan kewajiban-kewajibannya sebagai insan pribadi, sosial dan warga negara; (c) memberi rasa ketentraman, kekuatan dan kemakmuran potensipotensi rohani manusia melalui pendidikan kesabaran, keberanian, kesadaran, perenungan, optimisme dan pengadaan penelitian, Abdurrahman an-Nahlawi, Ushul al-Tarbiyyah al-Islam wa Asalibuha, Dar al-Fikr, Bairut, 1979, hlm. 13

${ }^{13}$ Zamakhsyari Dhofier, op.cit., hlm. 136

${ }^{14}$ Karel A. Steenbrink, Pesantren Madrasah Sekolah Pendidikan Islam dalam Kurun Modern, LP3ES, Jakarta, 1986, hlm. 152
} 
tuanya sendiri, atau saudaranya atau belajar di rumah tetangga (langgar). Pelajaran biasanya diberikan setelah shalat maghrib. Program pengajaran ini biasanya akan berhenti setelah anak dapat membaca sendiri al-Qur'an dengan lancar dan benar. Bagi beberapa anak dari keluarga tertentu yang punya hubungan dengan kyai atau guru mengaji, pendidikan pembacaan al-Qur'an hanya merupakan jenjang pertama. Mereka masih melanjutkan pelajaran untuk dapat membaca dan menterjemahkan buku-buku Islam klasik yang elementer yang ditulis dalam bahasa Arab. Sebagian dari mereka mempunyai ambisi untuk menjadi ulama, sehingga setelah berkenalan dengan beberapa kitab elementer, mereka memperdalam bahasa Arab sebagai alat untuk dapat memperdalam buku-buku fiqh, ushul fiqh, hadis, adab (sastra Arab), tafsir tauhid (teologi Islam), tarikh (sejarah Islam), tasawwuf, akhlak (etika Islam). Untuk menempuh mata-mata pelajaran tersebut diperlukan guru-guru yang cukup terdidik dan cukup berbobot. Ini dapat mereka peroleh di pesantren-pesantren. Untuk masa sekarang dapat diperoleh pada Institut Agama Islam Negeri (IAIN). ${ }^{15}$

\section{Santri}

Pengertian santri lebih tertuju kepada pesantren dengan sistem pendidikan tradisional sedangkan pada pendidikan modern yang menganut sistem barat di sebut siswa. Namun dalam pendidikan sistem tradisional pesantren ada dua macam santri. Pertama, Santri Mukim yaitu santri yang berasal dari daerah yang jauh dan menetap dalam kelompok pesantren, dan mereka juga mempunyai tanggung Jawab mengurusi kepentingan pesantren sehari-hari. Kedua, Santri Kalong yaitu santri yang berasal dari desa-desa di sekeliling pesantren, yang biasanya tidak menetap di dalam pesantren. Untuk mengikuti kegiatan pesantren, mereka pulang pergi dari rumahnya sendiri. Keberadaan jumlah santri mukim dan santri kalong menjadi cerminan besar dan majunya sebuah pondok pesantren. Semaikin besar jumlah santri mukim, maka semakin besar sebuah pesantren. Dan pesantren kecil jumlah santri kalongnya lebih banyak dari jumlah santri mukimnya.

Keberadaan santri di pondok pesantren dan menetap di asrama dengan berbagai alasan antar lain:

\footnotetext{
${ }^{15}$ Nurcholis Madjid, op.cit., hlm. 20
} 
a. Ia ingin mempelajari kitab-kitab lain yang membahas Islam secara lebih mendalam di bawah bimbingan kyai yang memimpin pesantren tersebut.

b. Ia ingin memperoleh pengalaman kehidupan pesantren, baik dalam bidang pengajaran, keorganisasian maupun hubungan dengan pesantren-pesantren yang terkenal.

c. Ia ingin memusatkan studinya di pesantren tanpa disibukkan oleh kewajiban sehari-hari di rumah keluarganya. Di samping itu, dengan tinggal di pesantren yang sangat jauh letaknya dari rumah tidak memungkinkannya untuk pulang bolak-balik.

\section{Kyai}

Dalam tradisi pesantren banyak memiliki kemiripan dengan tradisi yang ada dalam tasawuf, dalam hal ini tarekat. Misalnya saja dalam persoalan penghormatan kepada kyai, sikap hormat kepada kyai adalah ajaran yang mendasar yang ditanamkan kepada santri. Bahkan kepatuhan itu disinyalir lebih penting dari mencari ilmu itu sendiri. $^{16}$

Penyebutan kyai di beberapa daerah berbeda-beda. Di Jawa barat sendiri orang yang memimpin pesantren di sebut dengan Ajengan, sedangkan di Jawa Timur di sebut Kyai. ${ }^{17}$ Perkembangan zaman membawa perubahan areal penamaan kyai tidak terbatas pada orang yang mempunyai atau memimpin pondok pesantren, akan tetapi beberapa orang yang mempunyai pengaruh besar di kalangan masyarakat walaupun tidak mempunyai pondok pesantren di sebut juga dengan kyai. Sebutan kyai pada masa penjajahan mempunyai kedudukan yang prestise, karena kesultanan pada masa itu lebih banyak mengurus masalah politik, maka secara otomatis bidang agama dipegang oleh kyai. Karena cakupan bidang agama melingkupi segala aspek seperti, hak milik, perkawinan, perceraian, harta warisan, dan lain-lain, kekuasan kyai lebih besar dari pada kesultanan atau raja pada masa itu. Oleh karena itu, mereka lebih diterima secara umum di nusantara dan bahkan pada masa kemerdekaan banyak di antara mereka

\footnotetext{
${ }^{16}$ Syahrul 'Adam Mf, 'Pesantren: Kiai dan Tarekat (Satu Potret Sejarah Sosial Pendidikan Islam Indonesia), dalam Suwito MA dan Fauzan, Sejarah Sosial Pendidikan Islam, Kencana, Jakarta, 2008, hlm. 272

${ }^{17}$ Ibid., hlm. 273
} 
diangkat menjadi menteri, anggota parlemen, duta besar, dan pejabat-pejabat tinggi pemerintahan.

Bila ditelusuri lebih mendalam, keberadaan kyai dalam sejarah pondok pesantren adalah salah satu yang sangat vital, karena keberlangsungan pesantren tergantung dari peran kyai di dalamnya. Ronald Alan yang dikutip Hilmy mengatakan, kyai adalah cendekiawan agama (ulama) yang karenav Islam tidak memiliki sistem kependekatan, menjadi pemimpin-pemimpin Islam di Jawa. Kyai tidak memperoleh gelar dari sistem pendidikan formal, tetapi lebih dari itu, gelar itu datang dari masyarakat. ${ }^{18}$ Simuh menambahkan, sejak zaman Majapahit para kyai sangat ditaati para santri dan dimuliakan laksana raja-raja lokal tak bermahkota. Malah ada di antaranya menjelma menjadi kesultanan, yakni Demak, Surabaya, dan lainnya. ${ }^{19}$ Karena pengaruh kyai yang cukup besar di masyarakat, menempatkan kyai sebagai kelompok "elite", baik di tingkat nasional maupun daerah. Sejak Indonesia merdeka, sebagian mereka diangkat menjadi anggota di lembaga legislatif dan menjadi duta-duta besar. ${ }^{20}$

Secara umum, penyebutan kyai dalam sejarah pesantren atau masyarakat Islam di Jawa mempunyai tiga pandangan berbeda antara lain:

a. Sebagai gelar kehormatan bagi barang-barang yang dianggap keramat seperti, "Kyai Gadura Kencana" dipakai untuk sebutan kereta emas yang ada di keraton Yogyakarta.

b. Gelar kehormatan untuk orang-orang tua pada umumnya

c. Gelar yang diberikan oleh masyarakat kepada seorang ahli agama Islam yang memiliki atau menjadi pemimpin pesantren dan mengajar kitab-kitab Islam klasik kepada para santrinya.

Berangkat dari beragamnya penggunaan istilah kyai, maka tidak benar menurut Aliy As'ad, bila mengatakan bahwa kyai mesti ahli agama Islam. Menurut As'ad, gelar kyai digunakan dalam tiga dimensi: pertama, kyai ulama seperti Kyai Hasyim Asy'ari, Kyai Mahfudz al-Termasi, dan lain-lain. Kedua, Kyai sebutan, artinya sebutan kepada yang mempunyai kelebihan, mereka juga mempunyai pendukung untuk mengakui

\footnotetext{
${ }^{18}$ Hilmy Muhammadiyah dan Sulthan Fatoni, op.cit., hlm. 110

${ }^{19}$ Simuh, Islam dan Pergumulan Budaya Jawa, Teraju, Jakarta, 2003, hlm. 66

${ }^{20}$ Daud Rasyid, Islam dalam Berbagai Dimensi, Usamah Press, Jakarta, 2003, hlm. 297
} 
kelebihannya. Ketiga, Kyai aku-akuan yakni kyai yang sebetulnya tidak mempunyai kelebihan spritual apa-apa. ${ }^{21}$

Untuk mengetahui siapa yang layak disebut kyai, mesti harus ada parameter yang jelas. Syahrul Adam yang mengutip Abuddin Nata ${ }^{22}$ menyebutkan, bahwa kyai secara keilmuan mempunyai ciri-ciri, (1) menguasai ilmu agama secara mendalam; (2) keilmuan yang dimiliki telah mendapat pengakuan dari masyarakat sekelilingnya; (3) menguasai kitab kuning dengan matang; (4) taat beribadah kepada Allah SWT; (5) mempunyai kemandirian dalam bersikap; (6) tidak mau mendatangi penguasa; (7) mempunyai geneologi ke-kyai-an; (8) memperoleh ilham dari Allah.

\section{Kitab-kitab Islam Klasik}

Unsur pokok lain yang cukup membedakan pesantren dengan lembaga pendidikan lain adalah bahwa pada pesantren diajarkan kitab-kitab klasik yang dikarang para ulama terdahulu, mengenai berbagai macam ilmu pengetahuan agama Islam dan bahasa Arab. Pelajaran dimulai dengan kitab-kitab yang sederhana, kemudian dilanjutkan dengan kitab-kitab tentang berbagai ilmu yang mendalam. Dan tingkatan suatu pesantren dan pengajarannya biasanya diketahui dari jenis-jenis kitab yang diajarkan.

Keseluruhan kitab klasik yang diajarkan di pesantren dapat digolongkan kepada 8 kelompok: a. Nahwu; b. Fiqh; c. Usul fiqh; d. Hadis; e. Tafsir; f. Tauhid; g. Tasawuf dan etika; h. Cabang-cabang lain seperti tarikh dan balaghah. ${ }^{23}$ Kitab-kitab tersebut meliputi teks yang sangat pendek sampai teks yang terdiri dari berjilid-jilid tebal mengenai hadis, tafsir, fiqh, ushul fiqh dan tasawuf. Kesemuanya dapat digolongkan kepada tiga kelompok yaitu: 1. kitab-kitab dasar; 2. kitab-kitab tingkat menengah; 3. kitab-kitab besar.

\section{Kesimpulan}

Karakteristik pendidikan di pesantren digolongkan kepada dua : (a). Pola Umum Pendidikan. Dimulai dari tingkatan pengajian yang paling rendah yakni dimulai pada

\footnotetext{
${ }^{21}$ Aliy As'ad, 'Pendahuluan Terjemahan Kitab Ta'lim Muta'allim” dalam Aliy As'ad, Bimbingan bagi Penuntut Ilmu (Terjemahan Ta'lim al-Muta'allim), Menara Kudus, Kudus, tt., hlm. vii

${ }^{22}$ Syahrul 'Adam Mf, op.cit., hlm. 273

${ }^{23}$ Zamakhsyari Dhofier, op.cit., hlm. 50
} 
waktu anak-anak berumur sekitar 5 sampai 7 tahun dalam bentuk membaca atau menghafalkan surat-surat pendek dari Al-Qur'an yang dikenal dengan nama turutan, yang dilanjutkan, secara bertahap, membaca seluruh Al-Qur'an sampai lancar. Untuk mencapai taraf ini biasanya diperlukan waktu sekitar 5 atau 6 tahun. Kemudian Pengajian pada tingkat yang lebih tinggi berbentuk penerjemahan teks-teks Islam klasik yang masih bersifat elementer baik yang mengenai tata bahasa Arab, hukum-hukum Islam maupun teologi Islam. Setelah murid dianggap qualified untuk meneruskan pelajarannya ke lembaga-lembaga pesantren yaitu sekitar 15 atau 16 tahun. Lembagalembaga pesantrenpun mengenalkan tingkatan-tingkatan, dari yang mengajarkan teksteks sederhana sampai kepada pesantren luhur yang mengajarkan teks-teks tingkat tinggi. (b). Sistem Pengajaran, yaitu sistem sorogan, sistem ini merupakan sistem pengajian dasar di rumah-rumah, di langgar dan di masjid yang diberikan secara individual. Sistem bandongan, dalam sistem ini sekelompok murid mendengarkan seorang guru yang membaca, menerjemahkan kata demi kata, dan menerangkan maksudnya. Santri menyimak kitab masing-masing dan mendengarkan dengan seksama terjemahan dan penjelasan kyai. Kemudian santri mengulang dan mempelajari kembali sendiri-sendiri.

Unsur-unsur kelembagaan di pesntren adalah: 1. Pondok, tempat tinggal atau asrama para santri, untuk mengikuti dengan baik pelajaran yang diberikan oleh kyai; 2 . Masjid, sebagai lembaga pendidikan, berfungsi sebagai penyempurna pendidikan dalam keluarga dan juga menyelenggarakan dua macam starata pendidikan yaitu pendidikan dasar, yang disebut pengajian al-Qur'an, pendidikan ini berada di bawah bimbingan guru mengaji al-Qur'an. Dan yang kedua, pendidikan tingkat lanjutan yang disebut Guru Kitab. 3. Santri, terbagi dua yaitu: Santri Mukim (santri yang berasal dari daerah yang jauh dan menetap dalam kelompok pesantren); Santri Kalong (santri yang berasal dari desa-desa di sekeliling pesantren). 4. Kyai, yang menurut As'ad, digunakan dalam tiga dimensi: pertama, kyai ulama, kyai sebutan, dan kyai aku-akuan. 5. Kitab-kitab Islam Klasik, yang digolongkan kepada 8 kelompok: a. Nahwu; b. Fiqh; c. Usul fiqh; d. Hadis; e. Tafsir; f. Tauhid; g. Tasawuf dan etika; h. Cabang-cabang lain seperti tarikh dan balaghah. 


\section{E. Daftar Kepustakaan}

Abdurrahman an-Nahlawi, Ushul al-Tarbiyyah al-Islam wa Asalibuha, Dar al-Fikr, Bairut, 1979

Abdurrahman Wahid, Bunga Rampai Pesantren, Dharma Bakti, Jakarta, 1984

Aliy As'ad, "Pendahuluan Terjemahan Kitab Ta'lim Muta'allim” dalam Aliy As'ad, Bimbingan bagi Penuntut Ilmu (Terjemahan Ta'lim al-Muta'allim), Menara Kudus, Kudus, tt.

Amin Rais, Cakrawala Islam, Antara Cita dan Fakta, Mizan, Bandung, 1989

Daud Rasyid, Islam dalam Berbagai Dimensi, Usamah Press, Jakarta, 2003

Depag RI, Pedoman Pembinaan Pondok Pesantren, Ditjen. Binbaga Islam, Jakarta, 1985

Hasan Langgulung, Asas-asas Pendidikan Islam, al-Husna Dzikra, Jakarta, 1988

Hilmy Muhammadiyah dan Sulthan Fatoni, NU Identitas Islam Indonesia, Elsas, Jakarta, 2004

Karel A. Steenbrink, Pesantren Madrasah Sekolah Pendidikan Islam dalam Kurun Modern, LP3ES, Jakarta, 1986

Mahmud Yunus, Sejarah Pendidikan Islam di Indonesia, Hidakarya Agung, Jakarta, 1985

Nurcholis Madjid, Bilik-bilik Pesantren, Paramadina, Jakarta, 1997

Simuh, Islam dan Pergumulan Budaya Jawa, Teraju, Jakarta, 2003

Syahrul 'Adam Mf, "Pesantren: Kiai dan Tarekat (Satu Potret Sejarah Sosial Pendidikan Islam Indonesia), Suwito MA dan Fauzan, Sejarah Sosial Pendidikan Islam, Kencana, Jakarta, 2008

Zamakhsyari Dhofier, Tradisi Pesantren, LP3ES, Jakarta, 1982 
